\title{
PENGARUH PERCEIVED EASE OF USE, PERCEIVED USEFULNESS DAN TRUST TERHADAP REPURCHASE INTENTION
}

\author{
I Gusti Agung Ayu Permata Saraswati ${ }^{1}$ I Ketut Rahyuda ${ }^{2}$
}

Article history:

Submitted: 18 November 2020

Revised: 3 Desember 2020

Accepted: 5 Januari 2021

\section{Keywords:}

Perceived ease of use:

Perceived usefulness; Trust; Repurchase intention

\section{Kata Kunci:}

Perceived ease of use; Perceived usefulness; Trust; Repurchase intention

\section{Koresponding:}

Fakultas Ekonomi dan Bisnis, Universitas Udayana,Bali, Indonesia

Email:

gungsarasw@gmail.com ${ }^{1}$
Abstract

Repurchase intention is the behavior of consumers to repurchase products or services from the same company based on their previous purchase experience. The factors that influence the occurrence of repurchase intention include perceived ease of use, perceived usefulness, and trust. The purpose of this study was to determine the influence of these factors on Shopee users in Denpasar City. The study used a sample size of 140 Shopee user respondents in the city of Denpasar, with a nonprobability sampling method, particularly purposive sampling. Collecting questionnaire data using Google Forms to respondents. The data analysis technique used is multiple linear regression analysis. The results of this study indicate that (1) perceived ease of use has a positive and significant effect on repurchase intention (2) perceived usefulness has a significant positive effect on repurchase intention (3). trust has a significant positive effect on repurchase intention. Based on this, it can be concluded that perceived ease.of use, perceived.usefulness, and good trust greatly affect the repurchase.intention behavior of Shopee users in Denpasar City. Shopee management should pay attention to perceived ease.of use, perceived.usefulness, and trust in order to maintain repurchase.intention behavior.

\begin{tabular}{l} 
Abstrak \\
\hline Faktor-faktor yang mempengaruhi terjadinya perilaku repurchase \\
intention diantaranya yaitu perceived ease of use, perceived usefulness, dan \\
trust. Tujuan penelitian ini adalah untuk mengetahui pengaruh faktor- \\
faktor tersebut pada pengguna Shopee di Kota Denpasar. Penelitian ini \\
menggunakan ukuran sampel sebanyak 140 responden pengguna Shopee \\
di Kota Denpasar dengan menggunakan metode purposive sampling dalam \\
pengambilan sampelnya. Penyebaran kuesioner dilakukan dengan \\
menggunakan bantuan Google Formulir kepada responden. Analisis \\
regresi linear berganda adalah teknik analisis data yang digunakan dalam \\
penelitian ini. Hasil penelitian ini memberikan hasil bahwa (1) \\
perceived ease of use berpengaruh positif dan signfikan terhadap \\
repurchase intention (2) perceived usefulness berpengaruh positif \\
signifikan terhadap repurchase intention (3) trust berpengaruh positif \\
signifikan terhadap repurchase intention. Berdasarkan hal ini disimpulkan \\
bahwa perceived ease of use, perceived usefulness, dan trust yang baik \\
sangat mempengaruhi perilaku repurchase intention pada pengguna \\
Shopee di Kota Denpasar.
\end{tabular}

Faktor-faktor yang mempengaruhi terjadinya perilaku repurchase intention diantaranya yaitu perceived ease of use, perceived usefulness, dan trust. Tujuan penelitian ini adalah untuk mengetahui pengaruh faktordi Kota Denpasar dengan menggunakan metode purposive sampling dalam pengambilan sampelnya. Penyebaran kuesioner dilakukan dengan an dalam penelitian ini. Hasil penelitian ini memberikan hasil bahwa (1) perceived ease of use berpengaruh positif dan signfikan terhadap repurchase intention (2) perceived usefulness berpengaruh positif signifikan terhadap repurchase intention (3) trust berpengaruh positif Shopee di Kota Denpasar.

Fakultas Ekonomi dan Bisnis, Universitas Udayana, Bali, Indonesia ${ }^{2}$

Email: krahyuda@gmail.com² 


\section{PENDAHULUAN}

Revolusi industri 4.0 mengubah perilaku masyarakat dalam berbelanja. Pola konsumsi konvensional mulai bergeser kepada cara yang lebih praktis dan cepat dengan memanfaatkan teknologi internet. Perkembangan teknologi informasi di dunia kini memungkinkan terciptanya dunia yang tanpa batas, salah satunya dengan adanya penggunaan internet. Salah satu pemanfaatan internet adalah adanya e-commerce yang merupakan sarana untuk melakukan transaksi berbasis internet (Hidayat, 2019). Penggunaan internet yang kian bertambah memberikan peluang yang besar bagi para pelaku bisnis dibidang e-commerce (Paryadi, 2019). Adanya e-commerce memberikan berbagai kemudahan dalam berbelanja, dimana konsumen tidak perlu datang ke suatu toko fisik, melainkan mereka hanya perlu mengunjungi situs yang dituju dan menentukan produk apa yang mereka butuhkan (Ikranegara, 2017). Menurut Turban et al. (2018), perdagangan elektronik atau electronic commerce adalah sistem pembelian dan penjualan dengan menggunakan dukungan internet dan intranet.

Data yang ditujukan pada iprice.co.id mengenai perilaku belanja online oleh konsumen pada tahun 2019 yang menunjukkan hasil bahwa Shopee adalah e-commerce dengan jumlah pengunjung web bulanan terbesar dengan total pengunjung web bulanan hampir mencapai 73 juta pengunjung, lalu dilihat berdasarkan peringkat pada Appstore dan Playstore, Shopee juga memimpin diperingkat pertama sebagai e-commerce yang paling banyak diunduh, dimana hal tersebut menunjukkan bahwa banyaknya masyarakat yang memiliki minat beli dalam berbelanja online melalui Shopee.

Penelitian terhadap perilaku belanja online oleh konsumen sangat penting dilakukan, mengingat bahwa pertumbuhan dan perkembangan e-commerce yang semakin pesat dapat mempengaruhi bagaimana perilaku belanja online oleh konsumen, khususnya mengenai perilaku repurchase intention. Perilaku repurchase intention oleh konsumen sangat berperan dalam kesuksesan dan keuntungan suatu toko online (Puspitasari \& Briliana, 2018). Repurchase intention atau niat pembelian kembali adalah sebuah keputusan individu setelah mendapatkan penilaian dari pembelian yang dilakukan sebelumnya dan berniat untuk melakukan pembelian kembali (Subagio et al., 2018). Repurchase intention merupakan suatu tindakan dari individu terhadap suatu layanan atau produk dan akan melakukan pembelian kembali di kemudian hari karena adanya suatu penilaian. Repurchase intention bisa digunakan untuk dapat memperkirakan peluang seorang konsumen dalam menjadi pelanggan jangka yang panjang dan dapat memberikan keuntungan yang stabil pada perusahaan atau mungkin sebaliknya (Meng et al., 2011). Repurchase intention dapat dipengaruhi oleh berbagai hal diantaranya yaitu adanya perceived ease of use, perceived usefulnes, dan trust yang dimiliki oleh konsumen (Wen \& Xu, 2011).

Menurut Wahyuningtyas \& Widiastuti (2015), perceived ease of use adalah suatu persepsi yang dimiliki seseorang tentang kemudahan dalam menggunakan suatu sistem. Perceived ease of use menggambarkan bagaimana persepsi pelanggan terhadap kesederhanaan dan kejelasan suatu situs $e$ commerce ketika pelanggan mencari informasi atau suatu produk (Ma'ruf, 2018). Terdapat dua motivasi yang akan menjadi dasar utama dalam membentuk minat dalam berbelanja online yakni motivasi intrinsik dan motivasi ekstrinsik. Salah satu dimensi dalam motivasi ekstrinsik adalah perceived ease of use. Perceived ease of use dapat menjadi sebuah tolak ukur bahwa seseorang percaya dan merasa suatu teknologi dapat dimengerti dan mudah dalam digunakan (Tyas \& Darma, 2017). Perceived ease of use dapat menggambarkan kesederhanaan suatu teknologi ketika pelanggan melakukan pembelian secara online (Li, 2016). Penelitian Anjani (2019) memberikan hasil bahwa perceived ease of use mempunyai pengaruh positif dan signifikan terhadap repurchase intention. Hasil yang serupa diungkapkan oleh Oktarini \& Wardana (2018); Murwanti \& Surakarta (2017); Cao et al. (2016); Alain Yee (2013) dengan hasil penelitiannya bahwa perceived ease of use berpengaruh secara positif dan signifikan terhadap repurchase intention. Hasil yang bertentangan dikemukakan 
oleh Oroh \& Rumokoy (2015) yang memberikan hasil bahwa perceived ease of use tidak berpengaruh secara signifikan terhadap repurchase intention. Adanya konsumen yang memiliki persepsi bahwa penggunaan suatu situs sulit dengan prosedur pembelian yang rumit merupakan salah satu hal yang harus diperhatikan oleh pelaku bisnis online.

Variabel selanjutnya yang dapat mempengaruhi perilaku repurchase intention adalah perceived usefulness. Perceived usefulness adalah persepsi kebermanfaatan yang dirasakan konsumen dengan melakukan belanja secara online yang akan berdampak pada adanya minat konsumen untuk melakukan pembelian kembali. Terdapat berbagai manfaat yang dapat dirasakan konsumen dengan berbelanja secara online diantaranya dapat memberikan suatu kemudahan dalam berbelanja, terciptanya keputusan belanja yang lebih baik, dan proses pembelian yang lebih mudah dan fleksibel (Purnami \& Nurcaya, 2015). Penelitian Anjani (2019) memberikan hasil bahwa perceived usefulness mempunyai pengaruh yang positif dan signifikan terhadap repurchase intention. Hasil penelitian lainnya dilakukan oleh Wen \& Xu (2011); Trisnawati et al. (2012); Setyorini \& Nugraha (2016) yang menyatakan bahwa perceived usefulness mempunyai pengaruh yang positif dan signifikan terhadap repurchase intention. Hasil yang bertentangan dikemukakan oleh Subagio et al. (2018) yang memberikan hasil bahwa perceived usefulness tidak berpengaruh signifikan terhadap repurchase intention. Penelitian yang dilakukan oleh Sullivan \& Kim (2018) juga memberikan hasil yang bertentangan bahwa perceived usefulness tidak berpengaruh signifikan terhadap repurchase intention, hal ini dikarenakan pembeli telah memiliki pengalaman sebelumnya dalam menggunakan produk yang mereka beli.

Trust merupakan salah satu hambatan dalam melakukan transaksi online di Indonesia, hal tersebut dikarenakan sulitnya membentuk kepercayaan konsumen terhadap situs tersebut. Ketika konsumen melakukan suatu transaksi secara online, konsumen tidak dapat bertemu secara langsung dengan pedagang untuk dapat mengetahui secara langsung produk seperti apa yang akan dimiliki (Nonis, 2019). Trust merupakan variabel yang tidak kalah penting dalam mempengaruhi perilaku repurchase intention (Pappas et al., 2014). Trust dapat menciptakan pondasi yang kuat untuk menentukan sukses atau tidaknya e-commerce kedepannya. Suatu transaksi bisnis akan lebih baik jika keduabelah pihak saling mempercayai (Anjani, 2019). Trust bisa diperoleh dari rekan bisnis dan dibangun mulai dari awal (Juniwati, 2015). Trust sangat penting bagi suatu perusahaan relasional dan menjadi salah satu dasar bagi terbentuknya hubungan yang strategis, tanpa adanya trust yang dimiliki konsumen, maka suatu hubungan tidak akan berjalan dalam jangka panjang (Ansyah, 2019). Penelitian Trivedi \& Yadav (2018) memberikan hasil penelitian bahwa trust memiliki pengaruh yang positif dan signifikan terhadap repurchase intention. Penelitian Chen \& Chou (2012) juga memberikan hasil yang serupa bahwa trust mempunyai pengaruh yang positif dan signifikan terhadap repurchase intention. Hasil penelitian yang relevan juga diungkapkan oleh Bulut (2015) yang menunjukkan bahwa trust memiliki pengaruh yang positif dan signifikan terhadap repurchase intention. Namun, hasil yang bertentangan dikemukakan oleh Ali (2016) dan Wen \& Xu (2011)yang memberikan hasil bahwa trust tidak berpengaruh secara signifikan terhadap repurchase intention.

Penelitian mengenai repurchase intention terhadap salah satu e-commerce dengan pengguna terbanyak di Indonesia yaitu Shopee, akan dapat menjadi bahan pertimbangan dan tolak ukur bagi manajemen Shopee dan toko online di Shopee dalam melakukan penjualan secara online kepada konsumen dan menjadi bahan evaluasi dalam menetapkan kebijakan dan strategi. Shopee merupakan sebuah platform e-commerce yang menyuguhkan sistem berbelanja online yang mudah, aman, dan cepat dengan sistem pembayaran dan dukungan logistik yang kuat (shopee.co.id). Shopee memiliki ragam produk yang ditawarkan seperti : kecantikan, fashion, elektronik, perlengkapan rumah, kesehatan, ibu dan bayi, perlengkapan olahraga, dan lain-lain. Aplikasi ini juga menyediakan layanan 
pembayaran untuk produk digital seperti pulsa, paket data, voucher game, listrik PLN, BPJS, PDAM, Telkom, TV Kabel, tiket event \& hiburan, dan tiket pesawat. Layanan tersebut juga didukung dengan adanya kemudahan dalam transaksi dan pengiriman. Metode pembayaran yang digunakan dapat melalui transfer bank, kartu, Indomaret, dan Alfamart. Sistem pengiriman yang disediakan Shopee bisa melalui JNE, J\&T Express, dan GO-SEND. Penelitian ini menggunakan tiga variabel bebas dan satu variabel terikat. Perceived ease of use $\left(X_{1}\right)$, perceived usefulness $\left(X_{2}\right)$, dan trust $\left(X_{3}\right)$ berperan sebagai variabel bebas dalam penelitian ini. Variabel terikat adalah variabel yang dipengaruhi atau yang menjadi sebab akibat karena adanya variabel bebas. Variabel terikat dalam penelitian ini adalah repurchase intention yang disimbolkan dengan $\mathrm{Y}$.

Kerangka konseptual berikut disusun untuk menjelaskan rangkaian hubungan antara variabel bebas terhadap variabel terikat. Dengan mengacu pada kajian pustaka dan berbagai rujukan pada penelitian sebelumnya, maka dapat ditentukan hubungan antara variabel bebas perceived ease of use $\left(X_{1}\right)$, perceived usefulness $\left(X_{2}\right)$, dan trust $\left(X_{3}\right)$ terhadap variabel terikat repurchase intention $(\mathrm{Y})$ yaitu sebagai berikut: perceived ease of use $\left(X_{1}\right)$ memiliki pengaruh yang positif dan signifikan terhadap repurchase intention $(\mathrm{Y})$, perceived usefulness $\left(X_{2}\right)$ memiliki pengaruh yang positif dan signifikan terhadap repurchase intention $(\mathrm{Y})$, trust $\left(X_{3}\right)$ memiliki pengaruh yang positif dan signifikan terhadap repurchase intention (Y), dan perceived ease of use, perceived usefulness, dan trust secara simultan memiliki pengaruh yang positif dan signifikan terhadap repurchase intention.

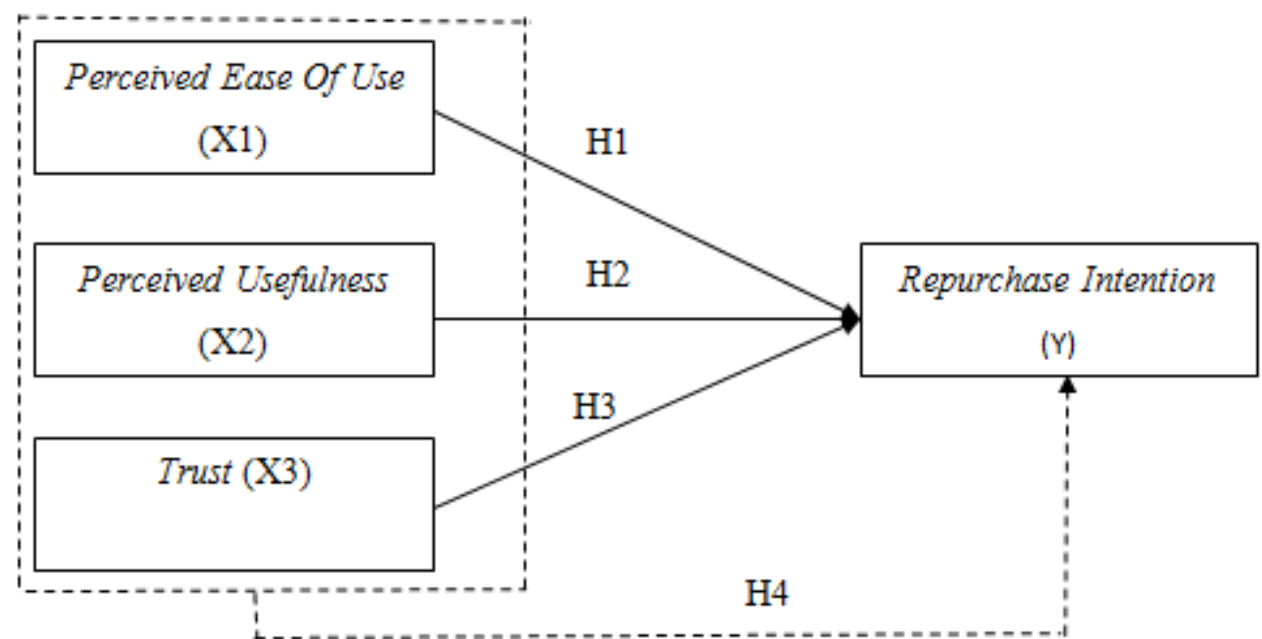

Gambar 1.

Kerangka Konsep Penelitian

Penelitian oleh Rezaei et al. (2014) memberikan hasil bahwa adanya persepsi terhadap mudahnya penggunaan suatu situs akan secara positif dan signifikan dapat mempengaruhi minat konsumen dalam melakukan pembelian kembali. Penelitian yang dilakukan oleh Juniwati (2015) dapat menunjukkan bahwa salah satu hal yang sangat penting bagi seorang pemasar adalah selalu memperhatikan kenyaman konsumen dengan adanya kemudahan dalam penggunaan serta prosedur pembelian yang dinilai dapat membantu meningkatkan ketertarikan konsumen dalam melakukan pembelian kembali disitus tersebut. Dengan mengacu pada teori dan berbagai rujukan penelitian sebelumnya, maka dapat ditentukan hipotesis sebagai berikut H1: Perceived ease of use berpengaruh positif dan signifikan terhadap repurchase intention 
Hasil penelitian dari Setyorini \& Nugraha (2016) mengungkapkan bahwa adanya perceived usefulness yang dirasakan konsumen dapat memberikan pengaruh yang positif dan signifikan terhadap repurchase intention. Hasil penelitian ini didukung pula oleh penelitian Purnami \& Nurcaya (2015) dengan hasil penelitiannya yang menunjukkan bahwa perceived usefulness yang dirasakan konsumen ketika berbelanja online dapat mendorong konsumen untuk melakukan pembelian kembali. Dengan mengacu pada teori dan berbagai rujukan penelitian sebelumnya, maka dapat ditentukan hipotesis sebagai berikut: $\mathrm{H} 2$ : Perceived usefulness berpengaruh positif dan signifikan terhadap repurchase intention.

Penelitian yang dilakukan oleh Bulut (2015) memberikan hasil bahwa trust yang dimiliki konsumen terhadap suatu perusahaan dapat memberikan pengaruh yang positif dan signifikan terhadap repurchase intention. Hasil penelitian tersebut didukung pula oleh penelitian Trisnawati et al. (2012) dengan hasil penelitiannya bahwa semakin tinggi trust konsumen terhadap suatu situs web, maka semakin meningkat pula minat konsumen dalam melakukan pembelian kembali. Dengan mengacu pada teori dan berbagai rujukan penelitian sebelumnya, maka dapat ditentukan hipotesis sebagai berikut: H3 : Trust berpengaruh positif dan signifikan terhadap repurchase Intention.

Hasil Penelitian dari Oroh \& Rumokoy (2015) memberikan hasil bahwa perceived ease of use, perceived usefulness, dan trust secara simultan mempunyai pengaruh yang signifikan terhadap repurchase intention. Adanya kemudahan dalam penggunaan suatu situs, persepsi kebermanfaatan serta kepercayaan yang tinggi oleh konsumen dapat meningkatkan minat konsumen dalam melakukan pembelian kembali. Hasil yang serupa juga diberikan oleh Cha (2011) yang mengungkapkan bahwa repurchase intention dapat dipengaruhi oleh berbagai faktor diantaranya oleh perceived ease of use, perceived usefulness, dan trust. Dengan mengacu pada teori dan rujukan penelitian sebelumnya, maka dapat ditentukan hipotesis sebagai berikut H4 : Perceived ease of use, perceived usefulness, dan trust secara simultan berpengaruh positif dan signifikan terhadap repurchase intention.

\section{METODE PENELITIAN}

Penelitian ini bersifat asosiatif yang bertujuan untuk mengungkapkan hubungan antara dua variabel atau lebih melalui pengujian hipotesis, yaitu pengaruh antara perceived ease of use $\left(X_{1}\right)$ dengan repurchase intention $(Y)$, pengaruh perceived usefulness $\left(X_{2}\right)$ dengan repurchase intention $(Y)$, dan pengaruh trust $\left(X_{3}\right)$ dengan repurchase intention $(Y)$. Jenis penelitian yang digunakan adalah penelitian yang bersifat kausal dengan alat bantu kuesioner yang diberikan kepada responden untuk dapat memperoleh data yang dibutuhkan. Penelitian kausal menunjukkan hubungan sebab-akibat salah satu variabel independen yang mempengaruhi variabel dependen. Penelitian ini dilakukan pada tahun 2020.

Penelitian ini dilakukan di Kota Denpasar, dimana Kota Denpasar merupakan pusat kota sekaligus Ibukota Provinsi Bali dengan jumlah penduduk yang sangat padat dan memiliki mobilitas serta tingkat konsumsi yang tinggi sehingga masyarakatnya berpeluang besar akan berusaha mencari alternatif-alternatif untuk dapat memudahkan kegiatan berbelanja mereka, salah satunya dengan menggunakan e-commerce dalam berbelanja. Perilaku konsumen adalah obyek dalam penelitian ini, khususnya yang membahas mengenai perilaku repurchase intention dalam berbelanja online menggunakan Shopee yang dipengaruhi oleh variabel perceived ease of use, perceived usefulness, dan trust.

Sumber data dalam penelitian ini yaitu berupa hasil jawaban kuesioner terkait variabel yang diteliti dan studi empiris pada penelitian sebelumnya mengenai variabel perceived ease of use, perceived usefulness, trust, dan repurchase intention serta data yang dikutip dari laporan iprice.com, 
google play dan data BPS tahun 2020 mengenai jumlah masyarakat di denpasar. Instrumen penelitian yang digunakan dalam penelitian ini adalah berupa angket atau kuesioner, yang dimaksudkan untuk menghasilkan data yang akurat yaitu dengan menggunakan skala likert.

Metode yang digunakan untuk menentukan sampel dalam penelitian ini adalah dengan teknik non probability sampling. Teknik ini dipilih karena jumlah populasinya yang tidak terbatas dan tidak dapat diketahui secara pasti seberapa besar jumlahnya. Penelitian ini memggunakan teknik non probability sampling yang berbentuk purposive sampling dengan menentukan pertimbangan tertentu dalam pengambilan sampel. Kriteria sampel yang ditentukan dalam penelitian ini adalah responden yang berdomisili di Kota Denpasar dan pernah membeli atau berniat membeli kembali suatu produk di Shopee

Metode yang digunakan dalam penelitian ini adalah metode kuantitatif. Analisis yang digunakan dalam penelitian ini adalah analisis regresi linear berganda (multiple regression). Analisis regresi linear berganda digunakan untuk menganalisis pengaruh antara variabel independen (Perceived ease of use, Perceived usefulness, Trust) terhadap variabel dependen yaitu Repurchase intention.

\section{HASIL DAN PEMBAHASAN}

Uji reliabilitas dapat menunjukkan seberapa besar suatu alat pengukuran dapat dipercaya atau dapat diandalkan. Pengujian reliabilitas dalam penelitian ini dapat dilakukan dengan melihat nilai koefisien cronbach alpha $(\alpha)$. Suatu konstruk atau variabel dikatakan reliabel jika memberikan nilai cronbach alpha $(\alpha)>0,6($ Ghozali, 2011).

Tabel 1

Hasil Uji Reliabilitas Instrumen Penelitian

\begin{tabular}{llll}
\hline No & Variabel & Cronbach Alpha & Keterangan \\
\hline 1 & Perceived Ease Of Use & 0,925 & Reliabel \\
2 & Perceived Usefulness & 0,931 & Reliabel \\
3 & Trust & 0,846 & Reliabel \\
4 & Repurchase Intention & 0,888 & Reliabel \\
\hline
\end{tabular}

Sumber: Data diolah, 2020

Tabel 1 menunjukkan hasil bahwa keseluruhan instrumen penelitian ini memiliki Cronbach Alpha lebih besar dari 0,6. Hal ini menunjukkan bahwa indikator yang digunakan dalam instrumen ini adalah reliabel atau memiliki kehandalan dalam mengukur variabel yang seharusnya diukur sehingga dapat digunakan dalam penelitian ini.

Nilai standardized coefficients regresi pada variabel perceived ease of use $\left(X_{1}\right)$ sebesar 0,269 memberikan makna bahwa setiap adanya peningkatan pada variabel perceived ease of use $\left(X_{1}\right)$ dengan asumsi bahwa variabel bebas lainnya konstan, maka tingkat repurchase intention akan mengalami peningkatan sebesar 0,269 . Hal ini dapat menunjukkan bahwa semakin baik perceived ease of use yang dirasakan oleh pengguna Aplikasi Shopee, maka perilaku repurchase intention akan semakin meningkat. Standardized coefficients regresi pada variabel perceived usefulness $\left(X_{2}\right)$ sebesar 0,413 menunjukkan bahwa setiap peningkatan variabel perceived usefulness $\left(X_{2}\right)$ dengan asumsi bahwa variabel bebas lainnya konstan, maka tingkat repurchase intention akan mengalami peningkatan sebesar 0,413. Hal ini menunjukkan bahwa bahwa semakin baik perceived usefulness yang dirasakan pengguna Aplikasi Shopee, maka perilaku repurchase intention akan semakin meningkat. Standardized coefficients regresi trust $\left(X_{3}\right)$ sebesar 0,259 menunjukkan bahwa setiap 
adanya peningkatan variabel trust $\left(X_{3}\right)$ dengan asumsi bahwa variabel bebas lainnya konstan, maka tingkat repurchase intention akan mengalami peningkatan sebesar 0,259 . Hal ini menunjukkan bahwa semakin baik trust yang dimiliki pengguna Aplikasi Shopee, maka perilaku repurchase intention akan semakin meningkat.

Tabel 2

Hasil Analisis Regresi Linier Berganda

\begin{tabular}{|c|c|c|c|c|c|}
\hline \multirow[b]{3}{*}{ Model } & \multicolumn{3}{|c|}{ Coefficients $^{\mathbf{a}}$} & \multirow[b]{3}{*}{$\mathrm{t}$} & \multirow[b]{3}{*}{ Sig. } \\
\hline & \multicolumn{2}{|c|}{ Unstandardized Coefficients } & \multirow{2}{*}{$\begin{array}{c}\text { Standardized } \\
\text { Coefficients } \\
\text { Beta }\end{array}$} & & \\
\hline & B & Std. Error & & & \\
\hline 1 (Constant) &,- 252 & 621 & &,- 405 & ,686 \\
\hline Perceived Ease Of Use & ,343 & ,085 & 269 & 4,031 &, 000 \\
\hline Perceived Usefulness &, 558 &, 104 & ,413 & 5,382 & ,000 \\
\hline Trust & ,265 & ,079 & ,259 & 3,344 &, 001 \\
\hline
\end{tabular}

a. Dependent Variable: Repurchase Intentio

Sumber: Data diolah, 2020

Tabel 3.

U.ji Normalitas

\begin{tabular}{llc}
\hline $\mathrm{N}$ & & Unstandardized Residual \\
Normal Parametersa,b & Mean & 140 \\
& Std. Deviation & .0000000 \\
Most Extreme Differences & Absolute & 1.58548982 \\
& Positive & .061 \\
Test Statistic & Negative & .051 \\
Asymp. Sig. (2-tailed) & & -.061 \\
\hline
\end{tabular}

Sumber: Data diolah, 2020

Hasil uji normalitas pada Tabel 3 dengan menggunakan Kolmogorov-Smirnov diperoleh bahwa nilai Asymp. Sig. (2-tailed) sebesar 0,200 yaitu lebih besar dari 0,05 (0,200>0,05). Hal ini menunjukkan bahwa data tersebut telah memenuhi syarat normalitas dan model regresi dalam penelitian ini dapat dinyatakan berdistribusi normal.

Tabel 4.

U.ji Multikolinearitas

\begin{tabular}{clccc}
\hline & & Variabel & \multicolumn{2}{c}{ Collinearity Statistics } \\
No & & Tolerance & VIF \\
& Perceived Ease Of Use & 0,440 & 2,272 \\
2 & Perceived Usefulness & 0,333 & 3,001 \\
3 & Trust & 0,327 & 3,057 \\
\hline
\end{tabular}

Sumber: Data diolah, 2020

Pengaruh Perceived Ease Of Use, Perceived Usefulnes dan Trust Terhadap Repurchase Intention I Gusti Agung Ayu Permata Saraswati dan I Ketut Rahyuda 
Berdasarkan Tabel 4 diperoleh bahwa nilai VIF pada masing-masing variabel bebas dalam penelitian ini lebih kecil dari 10. Variabel perceived ease of use memiliki nilai variance inflation factor (VIF) sebesar 2,272 < 10, variabel perceived usefulness sebesar 3,001 < 10, dan trust sebesar $3,057<10$. Hasil uji multikolinieritas membuktikan bahwa model regresi pada penelitian ini tidak mengalami geiala multikolinieritas.

Tabel 5.

Uji Heterokedastisitas

\begin{tabular}{|c|c|c|c|c|c|c|}
\hline \multirow{2}{*}{\multicolumn{2}{|c|}{ Model }} & \multicolumn{2}{|c|}{ Unstandardized Coefficients } & Standardized Coefficients & \multirow[b]{2}{*}{$\mathbf{T}$} & \multirow[b]{2}{*}{ Sig. } \\
\hline & & B & Std. Error & Beta & & \\
\hline \multirow[t]{4}{*}{1} & (Constant) & 1,940 & 0,377 & & 5,140 & 0,000 \\
\hline & Perceived ease Of Use & $-0,084$ & 0,052 & $-0,207$ & $-1,633$ & 0,105 \\
\hline & Perceived usefulness & $-0,025$ & 0,063 & $-0,059$ & $-0,403$ & 0,688 \\
\hline & Trust & 0,021 & 0,048 & 0,064 & 0,438 & 0,662 \\
\hline
\end{tabular}

Sumber: Data diolah, 2020

Berdasarkan hasil uji heterokedasitas, diperoleh hasil bahwa nilai signifikansi masingmasing variabel bebas lebih dari 0,05 . Variabel perceived ease of use memiliki nilai signifikansi sebesar 0,105 > 0,05. Variabel perceived usefulness memiliki nilai signifikansi sebesar 0,688>0,05, dan variabel trust memiliki nilai signifikansi 0,662 >0,05. Hal ini menunjukkan bahwa model regresi pada penelitian ini tidak ditemukan adanya gejala heterokedasitas.

Tabel 6.

Uii F

\begin{tabular}{llrrrrr} 
Model & & Sum of Squares & \multicolumn{1}{c}{ Df } & Mean Square & F & Sig. \\
\hline 1 & Regression & 962.741 & 3 & 320.914 & 124.907 & $.000^{\mathrm{b}}$ \\
& Residual & 349.415 & 136 & 2.569 & & \\
& Total & 1312.156 & 139 & & & \\
\hline
\end{tabular}

Sumber: Data diolah, 2020

Berdasarkan pada hasil uji $\mathrm{F}$ pada Tabel 6 diperoleh bahwa $\mathrm{F}$ hitung $=124,907$ dengan nilai signifikansi $0,000<0,05$. Hal ini menunjukkan bahwa perceived ease of use (X1), perceived usefulness (X2), dan trust (X3) berpengaruh secara serempak terhadap repurchase intention (Y) pada pengguna Aplikasi Shopee di Kota Denpasar.

Tabel 7.

Uji T

\begin{tabular}{lllll}
\hline \multicolumn{1}{c}{ Model } & t & Sig. & Hasil Hipotesis \\
\hline 1 & (Constant) & -.405 & .686 & \\
Perceived Ease Of Use & 4.031 & .000 & H1 diterima \\
Perceived Usefulness & 5.382 & .000 & H1 diterima \\
Trust & 3.344 & .001 & H1 diterima \\
\hline
\end{tabular}

Sumber: Data diolah, 2020

Pengaruh Perceived Ease Of Use, Perceived Usefulnes dan Trust Terhadap Repurchase Intention I Gusti Agung Ayu Permata Saraswati dan I Ketut Rahyuda 
Berdasarkan hasil uji t pada Tabel 7 diketahui bahwa perceived ease of use memiliki $t_{\text {hitung }}$ $=$ 4,031 dengan nilai signifikansi sebesar 0,000. Nilai sig. 0,000 lebih kecil dari 0,05, maka H0 ditolak dan $\mathrm{H} 1$ diterima. Hal ini menunjukkan bahwa perceived ease of use berpengaruh positif dan signifikan terhadap repurchase intention. Pada variabel perceived usefulness didapatkan nilai $t_{\text {hitung }}=$ 5,382 dengan nilai signifikansi sebesar 0,000. Nilai sig. 0,000 lebih kecil dari 0,05, maka H0 ditolak dan $\mathrm{H} 1$ diterima. Hal ini menunjukkan bahwa perceived usefulness berpengaruh positif dan signifikan terhadap repurchase intention. Pada variabel trust didapatkan nilai $t_{\text {hitung }}=3,344$ signifikansi sebesar 0,001 lebih kecil dari 0,05 yang menunjukkan bahwa H0 ditolak dan H1 diterima atau trust berpengaruh positif dan signifikan terhadap repurchase intention.

Tabel 8.

Koefisien Determinasi

\begin{tabular}{lrrrrr} 
Model & R & R Square & Adjusted R Square & \multicolumn{2}{c}{ Std. Error of the Estimate } \\
\hline 1 & $.857^{\mathrm{a}}$ & .734 & & .728 & 1.602881 \\
\hline Sumber: Data diolah, 2020 & & & &
\end{tabular}

Tabel 8 menunjukkan besarnya nilai $\mathrm{R}$ square sebesar 0,734 . Hal ini memiliki arti bahwa sebesar 73,4 persen variasi repurchase intention dipengaruhi oleh variasi perceived ease of use, perceived usefulness, dan trust. Sisanya sebesar 26,6 persen dijelaskan oleh variabel lain diluar model regresi yang digunakan dalam penelitian ini.

Berdasarkan pada pengujian statistik diperoleh bahwa pengaruh perceived ease of use terhadap repurchase intention memiliki nilai signifikansi t sebesar 0,000 dengan nilai koefisien beta sebesar 0,269. Nilai sig. t 0,000 yang lebih kecil dari 0,05 memiliki arti bahwa perceived ease of use berpengaruh positif dan signifikan terhadap repurchase intention. Semakin tinggi persepsi konsumen mengenai kemudahan dalam penggunaan Aplikasi Shopee, maka semakin meningkat pula tingkat perilaku repurchase intention. Hasil penelitian ini sejalan dengan hasil penelitian yang dilakukan oleh Apriyani \& Suharti (2017), Wicaksana \& Santika (2014), dan Rezaei et al. (2014) yang membuktikan bahwa perceived ease of use berpengaruh secara positif dan signifikan terhadap repurchase intention.

Berdasarkan pada pengujian statistik diperoleh bahwa pengaruh perceived usefulness terhadap repurchase intention memiliki nilai signifikansi t sebesar 0,000 dengan nilai koefisien beta sebesar 0,413. Nilai sig. t 0,000 yang lebih kecil dari 0,05 memiliki arti bahwa perceived usefulness berpengaruh positif dan signifikan terhadap repurchase intention. Semakin baik perceived usefulness yang dirasakan pengguna Aplikasi Shopee, maka semakin meningkat pula tingkat perilaku repurchase intention. Hasil pada penelitian ini sejalan dengan penelitian yang dilakukan Setyorini \& Nugraha (2016), Purnami \& Nurcaya (2015), Trisnawati et al. (2012), dan Wen et al. (2011)yang menyatakan bahwa perceived usefulness berpengaruh secara positif dan signifikan terhadap repurchase intention.

Berdasarkan pada pengujian statistik diperoleh bahwa pengaruh trust terhadap repurchase intention memiliki nilai signifikansi t sebesar 0,001 dengan nilai koefisien beta sebesar 0,259 . Nilai sig. t 0,001 yang lebih kecil dari 0,05 memiliki arti bahwa trust berpengaruh positif dan signifikan terhadap repurchase intention. Semakin baik trust yang dirasakan pengguna Aplikasi Shopee, maka semakin tinggi pula keinginan konsumen untuk melakukan pembelian kembali. Hasil penelitian ini sejalan dengan penelitian yang dilakukan oleh Ali (2016), Bulut (2015), Chen \& Chou (2012), Trisnawati et al. (2012), dan Wen \& Xu (2011)yang menyatakan bahwa trust berpengaruh positif dan signifikan terhadap repurchase intention. 


\section{SIMPULAN DAN SARAN}

Berdasarkan hasil penelitian yang telah diuraikan, maka dapat disimpulkan bahwa perceived ease of use berpengaruh positif dan signifikan terhadap repurchase intention pada pengguna Aplikasi Shopee di Kota Denpasar. Hal ini menunjukkan bahwa persepsi seseorang mengenai kemudahan dalam penggunaan Aplikasi Shopee yang semakin baik akan berdampak pada semakin meningkat pula tingkat perilaku repurchase intention. Adanya peningkatan kemudahan dalam penggunaan suatu situs akan memberikan rasa nyaman bagi konsumen ketika melakukan suatu pembelian disitus tersebut sehingga dapat meningkatkan minat dalam melakukan pembelian kembali. Perceived usefulness berpengaruh positif dan signifikan terhadap repurchase intention pada pengguna Aplikasi Shopee di Kota Denpasar. Hal ini menunjukkan bahwa adanya perceived usefulness yang baik dari pengguna Aplikasi Shopee akan berdampak pada semakin meningkat pula tingkat perilaku repurchase intention. Konsumen akan memiliki minat dalam melakukan pembelian kembali ketika mereka merasakan adanya manfaat atau keuntungan yang diterima dalam berbelanja disitus tersebut. Trust berpengaruh positif dan signifikan terhadap repurchase intention pada pengguna Aplikasi Shopee di Kota Denpasar. Hal ini menujukkan bahwa Semakin baik trust yang dirasakan oleh pengguna Aplikasi Shopee, maka semakin tinggi pula keinginan konsumen untuk melakukan pembelian kembali.

Berdasarkan hasil penelitian, terdapat tiga saran yang diberikan penulis yang diharapkan dapat membantu pihak manajemen Shopee terutama dalam meningkatkan minat pembelian kembali (repurchase intention) konsumen yang berada di Kota Denpasar serta saran kepada para peneliti selanjutnya. Hasil dari penelitian ini menunjukkan bahwa pada variabel perceived ease of use pada indikator mudah dipelajari dan mudah digunakan masih memiliki nilai dibawah rata-rata walaupun termasuk dalam kategori baik. Hal tersebut perlu diperhatikan oleh pihak manajemen Shopee dengan merancang proses pembelian yang lebih mudah dalam penggunaanya serta mudah dalam dipelajari oleh konsumen diberbagai tingkatan. Hasil dari penelitian ini yang masih perlu menjadi fokus selanjutnya yaitu variabel trust pada indikator kejujuran dan penepatan janji. Hal ini menunjukkan perlunya peningkatan pengawasan terhadap tampilan produk pada Aplikasi Shopee agar sesuai dengan produk yang akan diberikan kepada konsumen, selain itu juga diperlukan adanya jaminan bahwa janji terkait estimasi waktu penerimaan barang serta promosi produk yang ditampilkan benar adanya. Bagi peneliti selanjutnya, diharapkan dapat melakukan penelitian dengan cakupan yang lebih luas baik dengan menambah variabel lain diluar penelitian ini, memperluas cakupan yang tidak hanya berada pada wilayah Kota Denpasar saja serta masih perlu dilakukan pada perusahaan lain.

\section{REFERENSI}

Alain Yee-, L. C. (2013). Understanding mobile commerce continuance intentions: An empirical analysis of chinese consumers. Journal of Computer Information Systems, 53(4), 22-30.

Ali, T. (2016). Factors Deriving Consumers 'Repurchase Intention in Online Shopping : a Pakistani Consumer' s Perspective. International Journal of Management Sciences and Business Research, 5(12), 261-270.

Ansyah, A. (2019). Pengaruh Kepercayaan Dan Persepsi Risiko Terhadap Niat Pembelian Konsumen Pada Situs E-Commerce Lazada. Journal of Chemical Information and Modeling, 53(9), 1689-1699.

Apriyani, N., \& Suharti, S. (2017). Analisis Pengaruh Persepsi Kebermanfaatan, Persepsi Kemudahan Dan Kepercayaan Terhadap Minat Beli Ulang Pengguna Smartphone Xiaomi. Manajemen Dewantara, 1(1), 21.

Bulut, Z. A. (2015). Determinants Of Repurchase Intention In Online Shopping: A Turkish Consumer Perspective. International Journal Business And Social Science. Dokuz Eylül University. International Journal of Business and Social Science, 6(October 2015), 55-63.

Cao, T. K., Dang, P. L., \& Nguyen, H. A. (2016). Predicting consumer intention to use mobile payment services: Empirical evidence from Vietnam. International Journal of Marketing Studies, 8(1), 117-124.

Cha, J. (2011). Exploring the internet as a unique shopping channel to sell both real and virtual items: A comparison of factors affecting purchase intention and consumer characteristics. Journal of Electronic 
Commerce Research, 12(2), 115-132.

Chen, Y. T., \& Chou, T. Y. (2012). Exploring the continuance intentions of consumers for B2C online shopping: Perspectives of fairness and trust. Online Information Review, 36(1), 104-125.

Ghozali, I. (2011). Application of multivariate analysis with SPSS program. Semarang: Diponegoro University Publishing Agency.

Hidayat, J. N. (2019). Pengaruh Orientasi Belanja, Kepercayaan Online, Dan Persepsi Risiko Terhadap Minat Beli Secara Online Pada Tokopedia. 1-9.

Ikranegara, D. P. (2017). Pengaruh Orientasi Belanja, Kepercayaan Online, Dan Pengalaman Pembelian Terhadap Minat Beli Secara Online (Studi Kasus Pada Toko Online Bukalapak. 1(1), 1-10.

Juniwati, J. (2015). Pengaruh Perceived Ease of Use, Enjoyment dan Trust Terhadap Repurchase Intention dengan Customer Satisfaction Sebagai Intervening pada Belanja Online (Studi Pada Mahasiswa Universitas Tanjungpura Pontianak). Jurnal Ekonomi Bisnis Dan Kewirausahaan, 4(1), 140.

Li, Y. (2016). Empirical Study of Influential Factors of Online Customers' Repurchase Intention. IBusiness, $08(03), 48-60$.

Ma'ruf, S. (2018). The Influence Of Ease Of Use, Usefulness, Perceived Risk, And Convenience On Consumer Attitude On Online Shopping (A Case Study Of Lazada.Com) Oleh. Jurnal Fakultas Ekonomi, 3, 535549.

Meng, S., Liang, G., \& Yang, S. (2011). The relationships of cruise image, perceived value, satisfaction, and post-purchase behavioral intention on Taiwanese tourists. African Journal of Business Management, 5(1), 19-29.

Murwanti, S., \& Surakarta. (2017). Pengaruh Kulatias Pelayanan Dan Promosi Terhadap Minat Beli Ulang Jasa Service Motor Dengan Kepuasan Pelanggan Sebagai Variabel Mediasi ( Studi Pada Bengkel Motor Ahass Cabang UMS ). Manajemen Dan Bisnis, 9(2007), 207-227.

Nonis, M. F. (2019). Pengaruh Persepsi Keamanan, Kemudahan Bertransaksi dan Kepercayaan Konsumen terhadap Minat Beli secara Online pada Marketplace Shopee. STIE YKPN.

Oktarini, M. A. S., \& Wardana, I. M. (2018). Pengaruh Perceived Ease Of Use Dan Perceived Enjoyment Terhadap Customer Satisfaction Dan Repurchase Intention. INOBIS: Jurnal Inovasi Bisnis Dan Manajemen Indonesia, 1(2), 227-237.

Oroh, C., \& Rumokoy, F. (2015). the Influence of Perceived Ease of Use, Perceived Usefulness and Trust on Repurchase Intention of Lion Air E-Ticket. Jurnal Riset Ekonomi, Manajemen, Bisnis Dan Akuntansi, 3(3), 367-376.

Pappas, I. O., Pateli, A. G., Giannakos, M. N., \& Chrissikopoulos, V. (2014). Moderating effects of online shopping experience on customer satisfaction and repurchase intentions. International Journal of Retail and Distribution Management, 42(3), 187-204.

Paryadi, P. (2019). Pengaruh Kemudahan, Kepercayaan Dan Kualitas Informasi Terhadap Keputusan Pembelian Secara Online Pada Situs Lazada. Co. Id. Universitas Widya Dharma.

Puspitasari, I., \& Briliana, V. (2018). Pengaruh Perceived Ease-of-Use, Perceived Usefulness, Trust Dan Perceived Enjoyment Terhadap Repurchase Intention (Studi Kasus Pada Website Zalora Indonesia). Jurnal Bisnis Dan Akuntansi, 19(2), 171-182.

Rezaei, S., Amin, M., \& Ismail, W. K. W. (2014). Online repatronage intention: An empirical study among Malaysian experienced online shoppers. International Journal of Retail and Distribution Management, 42(5), 390-421.

Setyorini, R., \& Nugraha, R. P. (2016). The Effect of Trust Towards Online Repurchase Intention With Perceived Usefulness As An Intervening Variable: A Study on KASKUS Marketplace Customers. The Asian Journal of Technology Management, 9(1), 1-7.

Subagio, D. P. W., Mugiono, M., \& Hadiwidjojo, D. (2018). Pengaruh Perceived Ease of Use Terhadap Repurchase Intention dan Trust Sebagai Variabel Mediasi. Jurnal Manajemen Dan Kewirausahaan, 6(1), $35-44$.

Sugiyono, F. X. (2017). Neraca pembayaran: Konsep, Metodologi dan penerapan (Vol. 4). Pusat Pendidikan Dan Studi Kebanksentralan (PPSK) Bank Indonesia.

Sullivan, Y. W., \& Kim, D. J. (2018). Assessing the effects of consumers' product evaluations and trust on repurchase intention in e-commerce environments. International Journal of Information Management, 39(July 2017), 199-219.

Trisnawati, E., Suroso, A., \& Kumorohadi, U. (2012). Analisis Faktor-Faktor Kunci Dari Niat Pembelian Kembali Secara Online (Study Kasus Pada Konsumen Fesh Shop). Jurnal Bisnis Dan Ekonomi (JBE), 19(2), 126-141.

Tyas, E. I., \& Darma, E. S. (2017). Pengaruh Perceived Usefulness, Perceived Ease of Use, Perceived Enjoyment, dan Actual Usage Terhadap Penerimaan Teknologi Informasi: Studi Empiris Pada Karyawan Bagian Akuntansi dan Keuangan Baitul Maal Wa Tamwil Wilayah Daerah Istimewa Yogyakarta. Reviu 
Akuntansi Dan Bisnis Indonesia, 1(1), 25-35.

Wahyuningtyas, Y. F., \& Widiastuti, D. A. (2015). Analisis Pengaruh Persepsi Risiko, Kemudahan Dan Manfaat Terhadap Keputusan Pembelian Secara Online. Kajian Bisnis Sekolah Tinggi Ilmu Ekonomi Widya Wiwaha, 23(2), 112-120.

Wen, C., Prybutok, V. R., \& Xu, C. (2011). An integrated model for customer online repurchase intention. Journal of Computer Information Systems, 52(1), 14-23.

Wicaksana, I., \& Santika, I. (2014). Pengaruh Persepsi Kemudahan Penggunaan, Kegunaan Yang Dirasakan Dan Tingkat Pendidikan Terhadap Niat Berbelanja Kembali Pada Situs Tokobagus.Com. E-Jurnal Manajemen Universitas Udayana, 3(10), 255304.

https://iprice.co.id/trend/insights/laporan-belanja-online-e-commerce-indonesia/ diakses pada November 2020 